\title{
STUDI PEMBUATAN DODOL KELAPA (Cocos nucifera)
}

\author{
Yulianti \\ Dosen Teknologi Pangan, Fakultas Pertanian, Universitas Islam Indragiri \\ yulianti101@gmail.com
}

\begin{abstract}
Abstrak
Kelapa merupakan salah satu tanaman yang banyak di Indonesia khususnya di Kabupaten Indragiri Hilir, mengandung nilai gizi yang tinggi dan dapat diolah menjadi berbagai produk makanan. Pada penelitian ini telah dipelajari proses pembuatan Dodol dengan beberapa variasi formasi tepung beras ketan dan gula putih untuk mengetahui formasi terbaik dalam membuat dodol kelapa. Pengujian yang dilakukan yaitu uji kadar air dan uji organoleptik dengan parameter warna, rasa, aroma dan tekstur yang ditetapkan melalui uji skor dengan 15 jumlah panelis semi terlatih. Data yang diperoleh diolah dengan Rancangan Acak Lengkap dengan tiga kali ulangan. Hasil menunjukkan bahwa nilai kadar air tertinggi terdapat pada F1 sebesar $12,17 \%$ dan terendah pada perlakuan F3 yaitu 10, 47\% dan uji organoleptik menunjukkan tidak ada perbedaan yang nyata antar variasi namun perlakuan F3 adalah formulasi yang paling disukai panelis. Disimpulkan bahwa perlakuan F3 yaitu penambahan $50 \%$ tepung beras ketan dan $50 \%$ gula putih adalah formulasi terbaik untuk pembuatan Dodol daging buah kelapa.
\end{abstract}

Kata Kunci : Kelapa (Cocos nucifera), Dodol, Tepung, Gula putih

\section{PENDAHULUAN}

Buah kelapa merupakan salah satu produk tanaman tropis yang termasuk keluarga Arecaceae atau palem-paleman, tanaman kelapa menyebar diseluruh pelosok tanah air dan provini Riau merupakan sentra industri kelapa terbesar di Indonesia (Hadi, 2017) dimana $85 \%$ areal perkebunan kelapa di Riau berada di Kabupaten Indragiri Hilir, pada tahun 2017 terdapat sekitar 424.105 Ha areal perkebunan kelapa dengan produksi sebesar 338.740.133 Ton (BPS, Inhil 2018).

Buah kelapa berbentuk bulat yang terdiri dari 35\% sabut (eksokarp dan mesokarp), 25\% tempurung (endokarp), $28 \%$ daging buah (endosperm) dan $25 \%$ air (Palungkun, 2004). Daging buah kelapa segar baik pada tingkatan umur muda, setengah tua ataupun tua mengandung banyak zat kimia yang bermanfaat bagi tubuh diantaranya kalori, protein, lemak karbohidrat,vitamin dan kadar air (Direktorat gizi, 1981).

Kelapa dapat diolah menjadi berbagai macam produk, salah satunya dodol. Dodol merupakan salah satu jenis produk olahan hasil pertanian yang bersifat semi basah, berwarna putih sampai coklat yang dibuat dari daging buah matang yang dihancurkan dan campuran tepung ketan, gula dan santan (Soemaatmadja, 1997). Penambahan bahan dalam pembuatan dodol harus sesuai untuk mendapatkan dodol yang disukai masyarakat (Satuhu dan Sunarmani, 2004). Produk olahan dodol digemari masyarakat karena memiliki variai rasa dan harga yang terjangkau. 
Pada penelitian ini sampel daging buah kelapa diambil dari kelapa Desa Sialang Panjang Kecamatan Tembilahan Hulu Kabupaten Indragiri Hilir, Riau, Indonesia. Dodol dibuat dengan berbagai variasi formasi tepung beras ketan dan gula putih untuk mengetahui formasi terbaik dalam pembuatan dodol. Penerimaan konsumen terhadap dodol kelapa yang dihasilkan dilakukan dengan uji organoleptik.

\section{METODOLOGI PENELITIAN}

\section{Bahan}

Daging buah kelapa segar yang digunakan diambil dari kelapa (Cocos nucifera) Desa Sialang Panjang, Kecamatan Tembilahan Hulu, Indragiri Hilir, Riau dengan tingkatan umur setengah tua, tepung beras ketan putih (rose brand), gula putih, santan, air, plastik kelim, aluminium foil.

\section{Alat}

Alat yang digunakan berupa timbangan analitik, oven, cawan petri, desikator, blender, kompor, sendok, baskom, saringan, pengaduk, pisau dan wajan.

\section{Pelaksanaan Penelitian}

Penelitian dilaksanakan pada bulan Januari sampai Februari 2019 di Laboratorium Teknologi Pangan Fakultas Pertanian Universitas Islam Indragiri, Tembilahan, Indragiri Hilir Riau.

\section{Prosedur Penelitian}

\section{Pembuatan Dodol Kelapa}

Ekstrak santan dari tiga buah kelapa dimasak sambil terus diaduk, lalu dimasukkan bubur daging kelapa sebanyak 300 gr yang dibuat dari 6 butir kelapa setengah tua, selanjutnya dimasukkan tepung beras ketan dan gula putih sesuai dengan formula perlakuan penelitian kemudian diaduk secara merata hingga dodol kalis, setelah terbentuk dodol kemudian dikemas untuk dianalisa. Diagram alir pembuatan dodol kelapa dapat dilihat pada Gambar 1 .

Adapun formula yang diberikan dalam pembuatan dodol kelapa ini adalah sebagai berikut:

F1: 300 gram bubur daging buah kelapa $+30 \%$ tepung beras ketan $+40 \%$ gula putih

F1: 300 gram bubur daging buah kelapa $+40 \%$ tepung beras ketan $+45 \%$ gula putih

F1: 300 gram bubur daging buah kelapa $+50 \%$ tepung beras ketan $+50 \%$ gula putih

\section{Uji Kadar Air}

Analisa kadar air dilakukan dengan menghitung perbedaan berat sebelum dan setelah pengeringan (Sudarmadji dkk, 1997). Sampel ditimbang sebanyak 2 gram lalu dimasukkan kedalam cawan petri yang telah dikeringkan dalam oven pada suhu $100-105^{\circ} \mathrm{C}$ selama 3 jam, kemudian didinginkan dalam desikator selama 3 menit lalu ditimbang, hal ini dilakukan sampai diperoleh berat yang konstan.

\section{Uji Organoleptik}

Uji Organoleptik yang dilakukan meliputi warna, aroma, rasa dan tekstur menggunakan metode Hedonik berdasarkan tingkat kesukaan dan ketidaksukaan panelis dengan 15 jumlah panelis semi terlatih. Skor yang digunakan adalah 9 (amat sangat suka), 8 (sangat suka), 7 (suka), 6 (agak suka), 5 (biasa), 4 (kurang suka), 3 (tidak suka), 2 (sangat tidak suka) dan 1 (amat sangat tidak suka). 


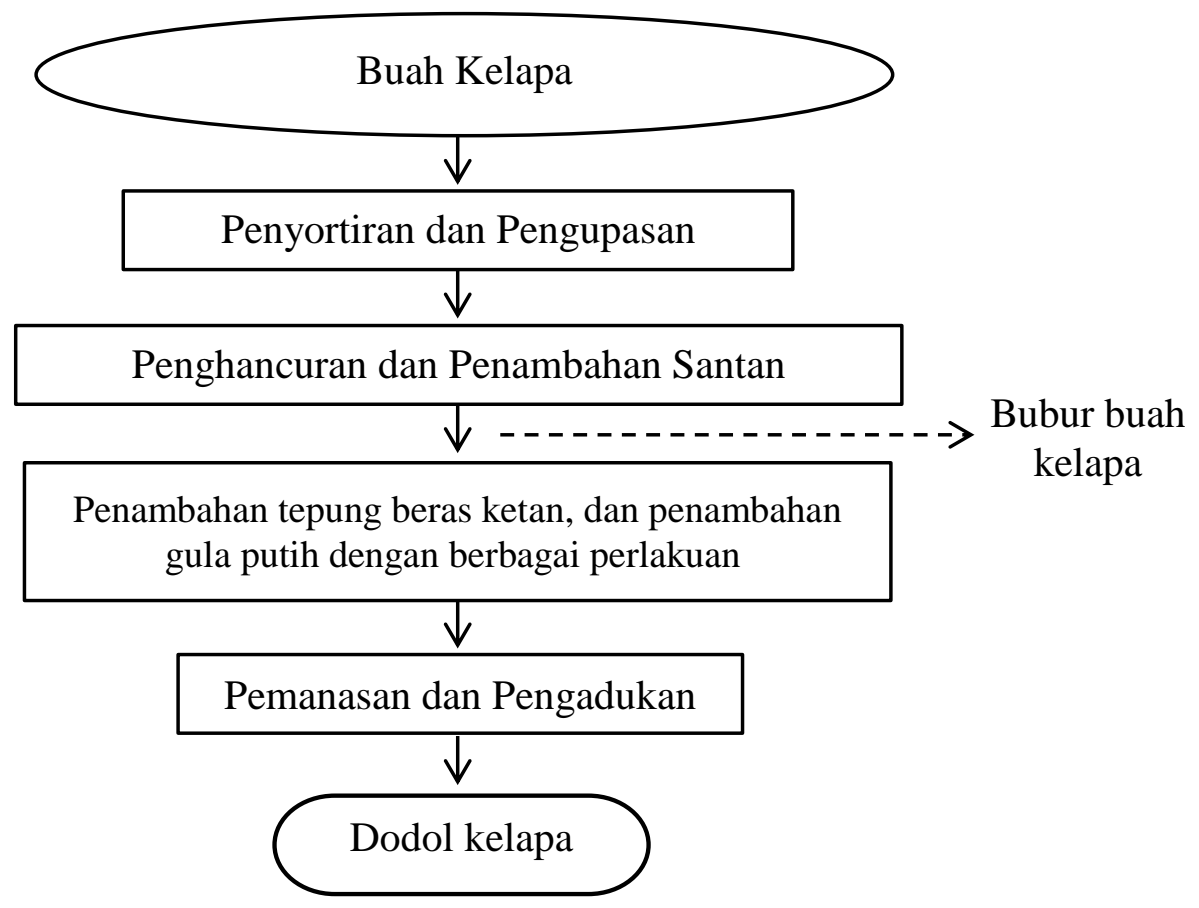

Gambar 1. Diagram Alir Pembuatan Dodol Kelapa

\section{HASIL DAN PEMBAHASAN}

\section{Kadar Air}

Kadar air pada bahan pangan menentukan ketahanan daya simpan, jumlah kadar air 20\% dalam suatu bahan pangan (dodol) sangat penting dalam menentukan kualitas daya simpan pangan tersebut (Syarief dan Anies,
1988). Dari hasil penelitian didapatkan bahwa nilai kadar air dari berbagai perlakuan juga berbeda-beda, kadar air tertinggi terdapat pada perlakuan $\mathrm{F} 1$ yaitu $12,17 \%$ dan nilai terendah pada $\mathrm{F} 3$ yaitu 10, 47\%. Kadar air menurun seiring dengan penambahan konsentrasi tepung beras ketan (Gambar 2).

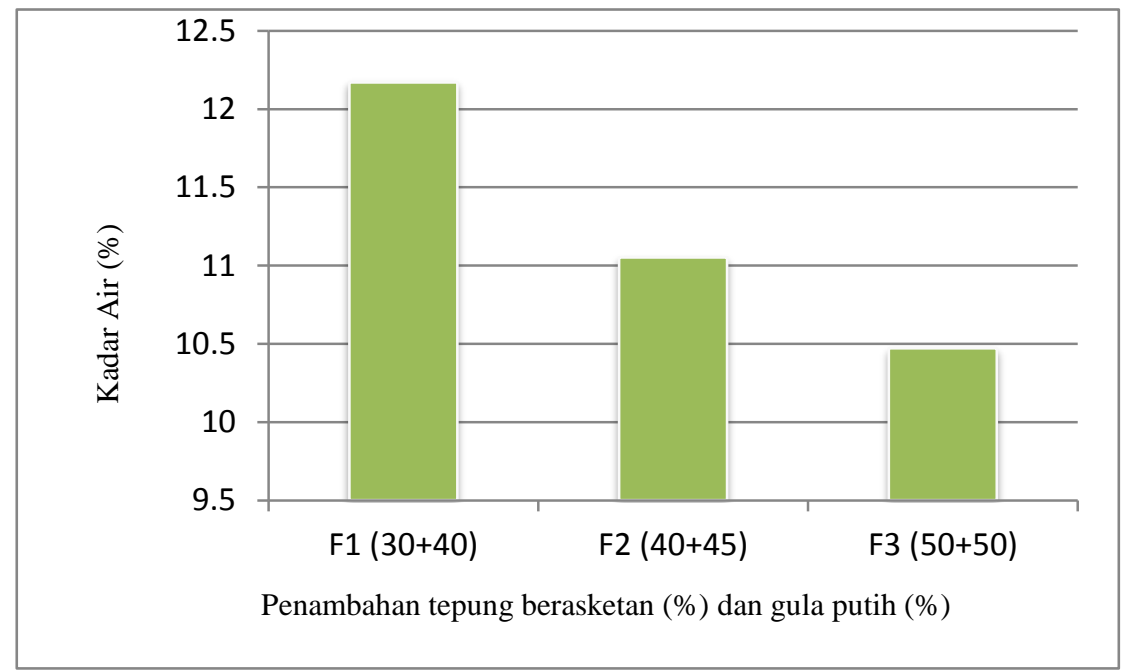

Gambar 2. Pengaruh Penambahan Tepung Beras Ketan dan Gula Putih terhadap Kadar Air Dodol Kelapa 


\section{Uji Organoleptik terhadap Dodol}

Proses pengadukan dan suhu pemanasan akan mempengaruhi hasil pembutan dodol namun tidak hanya itu perbandingan jumlah tepung dan gula sebagai bahan baku dodol juga sangat mempengaruhi kualitas dodol yang dihasilkan.

Berdasarkan parameter uji kesukaan untuk penerimaan panelis terhadap produk didapatkan bahwa panelis tidak memberikan penilaian yang berbeda nyata dari berbagai variasi formasi, yaitu suka sampai dengan sangat suka.

\section{Warna}

Secara visual warna akan menentukan kualitas makanan dan menarik perhatian konsumen yang dapat menimbulkan kesan suka atau tidak suka. Salah satu yang mempengaruhi kualitas warna makanan adalah adanya gula. Penambahan kadar gula yang tepat akan meghasilkan warna yang menarik. Hasil pengujian menunjukkan seluruh perlakuan dodol daging buah kelapa dapat diterima panelis. Penilaian terbaik adalah perlakuan F3 (50\% tepung beras ketan $+50 \%$ gula putih) yaitu sebesar 8 , 21 (sangat suka), menghasilkan warna dodol putih cerah sedangkan perlakuan F2 dan F1 warna dodol yang dihasilkan putih gelap (Gambar 3). Hasil analisa sidik ragam diketahui bahwa tidak terdapat perbedaan yang nyata pada taraf $5 \%$ dan $1 \%$ untuk seluruh perlakuan.

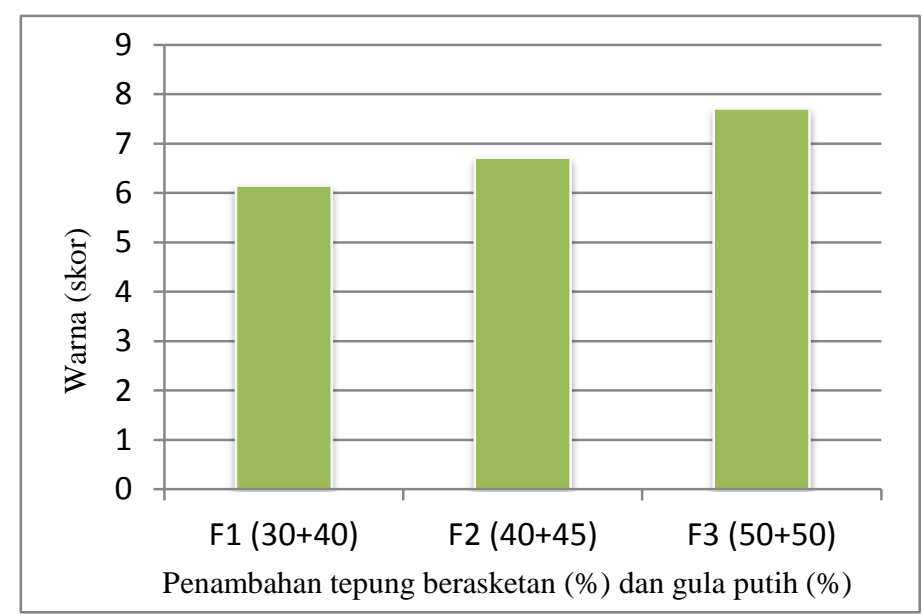

Gambar 3. Pengaruh Penambahan Tepung Beras Ketan dan Gula Putih terhadap Warna Dodol Kelapa

Rasa

Uji terhadap rasa lebih banyak melibatkan panca indra lidah, rasa makanan dapat dikenali dan dibedakan oleh kuncup-kuncup cecapan yang terletak pada papila yaitu bagian noda merah jingga pada lidah (F.G Winarmo, 2004). Pengaturan rasa pada makanan sangat penting dan rasa yang enak sangat menentukan penerimaan konsumen, khususnya pada pembuatan dodol kelapa, kelapa mengandung glukosa, fruktosa dan sukrosa yang menyebabkan kelapa terasa manis (Direktorat Gizi Depkes RI, 1981), maka penambahan gula yang tepat menjadi hal yang sangat penting karena jika berlebih akan menimbulkan rasa yang terlalu manis.

Uji sensorik terhadap rasa menunjukkan bahwa dodol kelapa yang dihasilkan secara keseluruhan dapat diterima oleh panelis, penilaian tertinggi terdapat pada perlakuan $\mathrm{F} 3$ yaitu sebesar 6,70 (suka), disusul perlakuan F2 5,80 
(agak suka) dan F1 5,61 (agak suka), dapat dilihat pada Gambar 4. Hasil analisa sidik ragam menunjukkan tidak ada perbedaan yang nyata pada taraf $5 \%$ dan $1 \%$. Perlakuan F3 menjadi formula yang paling disukai panelis, ini disebabkan penambahan kadar gula yang tepat sehingga rasa dodol tidak hambar dan tidak pula terlalu manis.

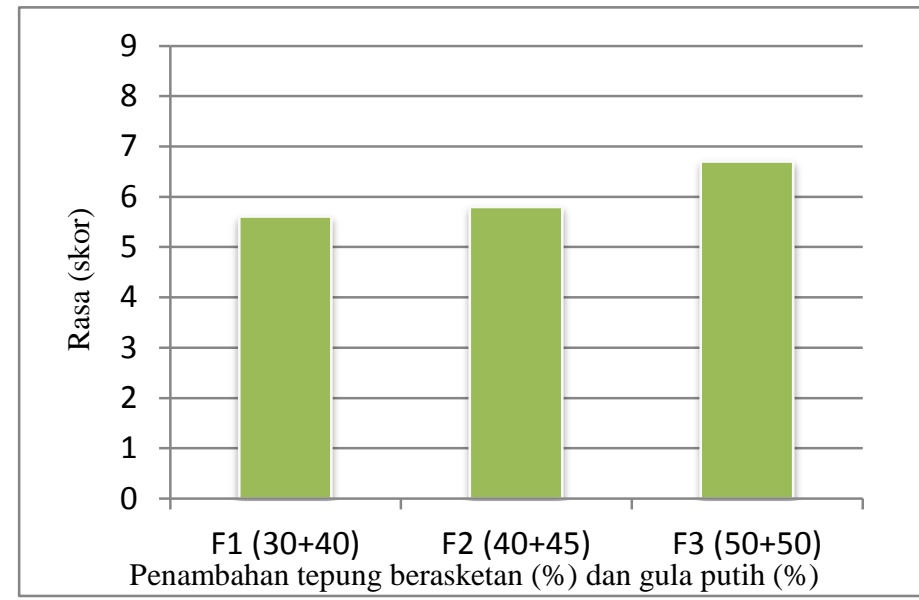

Gambar 4. Pengaruh Penambahan Tepung Beras Ketan dan Gula Putih terhadap Rasa Dodol Kelapa

\section{Aroma}

Aroma menjadi salah satu perhatian utama pada makanan, sesuai dengan Rubianti dan Berty 1985, bahwa setelah bau atau aroma diterima maka penentuan selanjutnya adalah cita rasa disamping teksturnya. Hasil uji aroma pada dodol kelapa menunjukkan bahwa produk dari tiga variasi perlakuan diterima panelis dengan sangat baik, hasil dari tiga perlakuan memberikan nilai yang tinggi, pada $F 17,50$ (sangat suka) dan pada F2 7,70 (sangat suka) dan pada F3 7,91(sangat suka), tidak ada perbedaan yang nyata (Gambar 5). Aroma yang disukai panelis sangat jelas berasal dari kelapa yang menjadi bahan pokok pembuatan dodol.

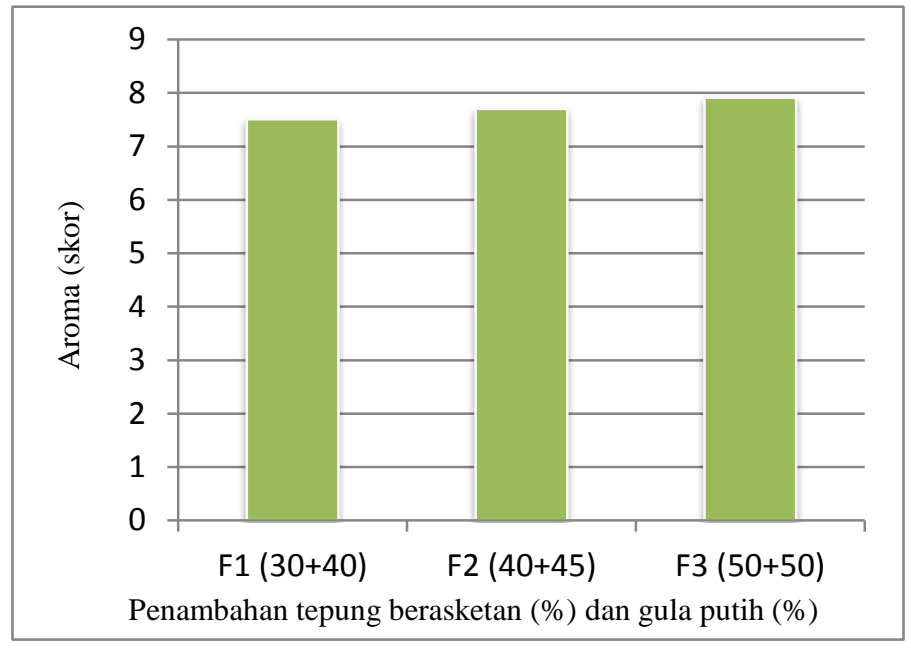

Gambar 5. Pengaruh Penambahan Tepung Beras Ketan dan Gula Putih terhadap Aroma Dodol Kelapa 


\section{Tekstur}

Tekstur merupakan salah satu sifat fisik dari bahan pangan, hal ini berhubungan dengan rasa pada waktu makanan dikunyah dan salah satu cara penentuan tekstur bahan pangan adalah dengan memberi beban bahan tersebut seperti tekanan jari (Rampengan dkk, 1985). Hasil uji organoleptik menunjukkan bahwa perlakuan F3 merupakan tekstur terbaik ditunjukkan dengan nilai 6,87 (suka), sementara F2 5,42 (agak suka) dan F1 4,67 (biasa). Terlihat pada Gambar 6 bahwa perlakuan F3 adalah formula yang paling disukai panelis. Penambahan gula mempengaruhi tekstur dodol yang dihasilkan, formula F3 adalah yang terbaik terlihat dari tekstur dodol yang kenyal, tidak keras dan tidak pula lembek sementara untuk perlakuan F2 dan F1 dodol yang dihasilkan terasa agak keras. Analisa sisik ragam menunjukkan perbedaan yang nyata pada taraf $5 \%$ dan $1 \%$, perbedaan yang nyata terdapat pada perlakuan F3 dan F2 serta F1, meskipun secara keseluruhan tekstur dodol kelapa yang dihasilkan dapat diterima panelis.

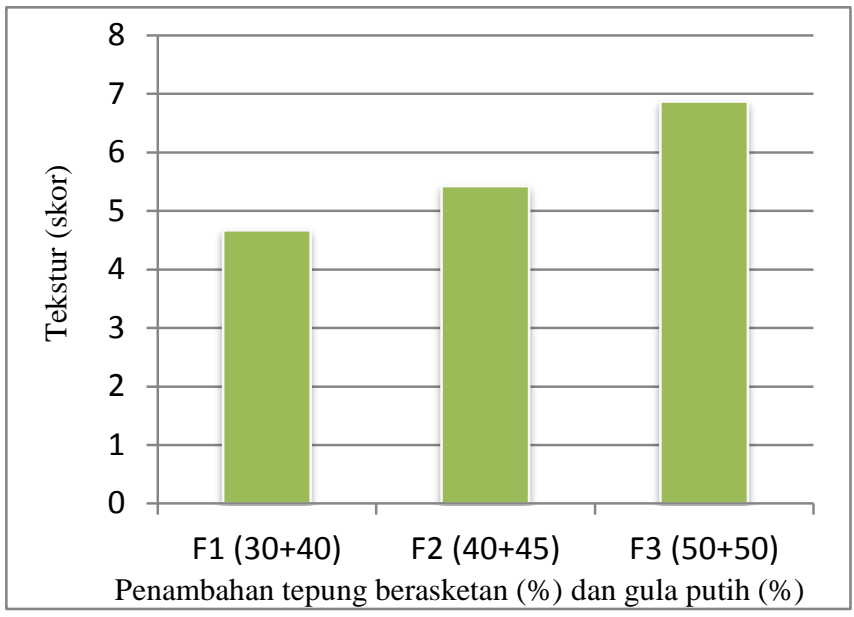

Gambar 6. Pengaruh Penambahan Tepung Beras Ketan dan Gula Putih terhadap Tekstur Dodol Kelapa

\section{KESIMPULAN}

Pada penelitian ini telah dibuat dodol kelapa yang dibuat dari daging buah kelapa, tepung berasketan dan gula putih yang dipanaskan pada suhu $80^{\circ} \mathrm{C}$ sambil diaduk selama 2 jam, di dapatkan nilai kadar air tertinggi terdapat pada perlakuan F1 dan terendah pada perlakuan F3. Sementara pada uji organoleptik warna, rasa, aroma dan tekstur diperoleh perlakuan terbaik adalah F3, meskipun untuk rasa tidak didapatkan nilai yang berbeda nyata. Disimpulkan perlakuan F3 merupakan formulasi terbaik dalam pembuatan dodol kelapa.

\section{DAFTAR PUSTAKA}

Direktorat Gizi Depkes RI.1981. Daftar Komposisi Bahan Makanan. Bratara Karya Aksara. Jakarta.

Hadi, Syaiful. 2017. Model Pengembangan Industri Kelapa di Provinsi Riau. Prosiding Seminar Nasional Perencanaan Pembangunan Inklusif Desa kota.

Hajiji, Ajid dkk. 2018. Statistik Daerah Kabupaten Indragiri Hilir 2018. Badan Pusat Statistik Kabupaten Indragiri Hilir.

Palungkun, R. 2004. Aneka Produk Olahan Kelapa. Penerbit Swadaya. Bogor. 
Rampengan, V.J dkk. 1985. Dasar- Soemaatmadja, 1997. Pengawetan Dasar Pengawasan Mutu Pangan. Badan Kerja Sama Perguruan Tinggi Negeri Indonesia Bagian Timur, Ujung Pandang. Pangan di Indonesia. IPB. Bogor. Sudarmadji, S dkk. 1997. Prosedur Analisa untuk Bahan Makanan dan Pertanian. Liberty. Yogyakarta.

Rubianty dan Berty Kaseger, 1985. Syarief, R., dan Anies I. 1988.

Kimia Pangan. Badan Kerjasama Perguruan Tinggi Negeri Indonesia Bagian Timur, Ujung Pandang.

Pengetahuan Bahan untuk Industri Pertanian. Mediyatama Sarana Perkasa. Jakarta.

Satuhu, S., dan Sunarmani 2004. Winarno F. G. 1992. Kimia Pangan dan Membuat Aneka Dodol Buah. Gizi. Jakarta: Gramedia Pustaka Penebar Swadaya. Jakarta. Utama. 